\section{Turkish Rangelands and Shrub Culture}

\begin{abstract}
Ali Koç
$\mathrm{T}$ Turkey is located between northern latitudes of $36^{\circ}-42^{\circ}$ and eastern longitudes of $26^{\circ}-45^{\circ}$ and covers 814.6 thousand $\mathrm{km}^{2}$. The average elevation is $1,100 \mathrm{~m}$ and average annual precipitation is $600 \mathrm{~mm}$. From recent statistical data, the land use in Turkey is; field crops (30\%), horticulture (5\%), forests $(20 \%)$, shrubs $(10 \%)$, rangelands $(25 \%)$, meadows $(1 \%)$ and the others (9\%).

Animal husbandry produces $5 \%$ of the gross national product (approximately 122 billion US \$) of Turkey. Twelve million animal units graze on Turkish rangelands. Most of these rangelands are located in the Central Anatolia, Eastern Anatolia and Southeastern Anatolian Regions. The average annual precipitation in these regions ranges between 200 and $600 \mathrm{~mm}$. As is always in the world's grazing lands, the rangelands of Turkey have problems.
\end{abstract}

\section{The State of Turkey's Rangelands}

Rangelands in Turkey are common property and every individual who lives in a village has a right to graze their animals on them. Currently, people start grazing at the first opportunity and continue yearlong depending on the conditions and regardless of the lands carrying capacity. Until recently, there was no legislation regulating the use of rangelands. A law recently introduced by parliament, however, will likely take 5-10 years to regulate proper use of these areas.

At present, the rangelands of Turkey are grazed 2 to 3 times higher than their carrying capacity. As a consequence of bad management, up to $90 \%$ of the climax vegetation of Turkey's rangelands has been lost (Genckan et al. 1990), and valuable range plants are scarce. Canopy cover has become sparser and moderate to severe erosion problems have appeared in more than $90 \%$ of the rangelands (Koç et al. 1994). Except for relatively light degradation of rangelands in Eastern Anatolia and high elevation rangelands, most Turkish rangelands have moderate to high levels of degradation. Koç (1995) reported that the canopy cover and forage production of Turkey's rangelands changed from $10 \%$ to $70 \%$, and from 450 to $1,200 \mathrm{~kg}$ ha, respectively, depending on the regional conditions. Heavy grazing began in the past decades, especially after developments in agricultural mechanization in the 1950's.

As a result, almost all of the rangelands of Turkey need improvements.

\section{The State of Turkey's Shrublands}

Although shrublands are regarded as grazing lands in most countries of the world, these lands are officially accepted as forestlands in Turkey. Utility regulations are overseen by the Ministry of Forestry and grazing is prohibited by the law. But, these lands are illegally grazed and suffer from overgrazing. Shrubland vegetation is common in Mediterranean Region and Aegean Region in Turkey. Shrublands of these regions include about 90 maquis (Evergreen shrubs and dwarf trees common in Mediterranean climate zone similar to chaparral in California) and 60 woody shrub species (Y1lmaz 1993). Herbaceous shrub species like Atriplex sp. and Artemisia sp. are common in Turkey's flora. Research on the forage value of these plants needs to be conducted in Turkey.

\section{The Importance of Shrubs in Range Improvement}

Rangelands in Turkey receive less than $900 \mathrm{~mm}$ annual precipitation and generally suffer from heavy grazing. Heavy grazing causes not only destruction of range vegetation but also degradation of the soils by erosion. Vegetation of heavily grazed rangelands in arid and semi arid regions has a tendency towards conversion to shrublands. For example, as a result of bad management of the rangelands in Eastern Anatolian Region in Turkey since the 1950's, thorny species of Astragalus (Fabaceae family having chamaephyt life form; cushion forming plants whose buds are held close to the soil surface) have increased in rangeland vegetation (Figure 1, 2).

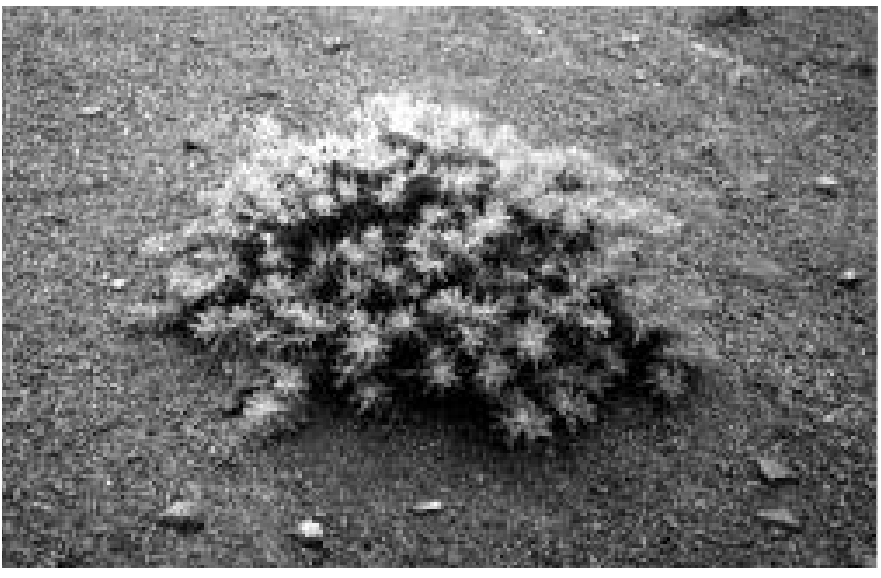

Fig. 1. A general view of Astragalus microcephalus Willd which is wide spread in the rangelands in Turkey.

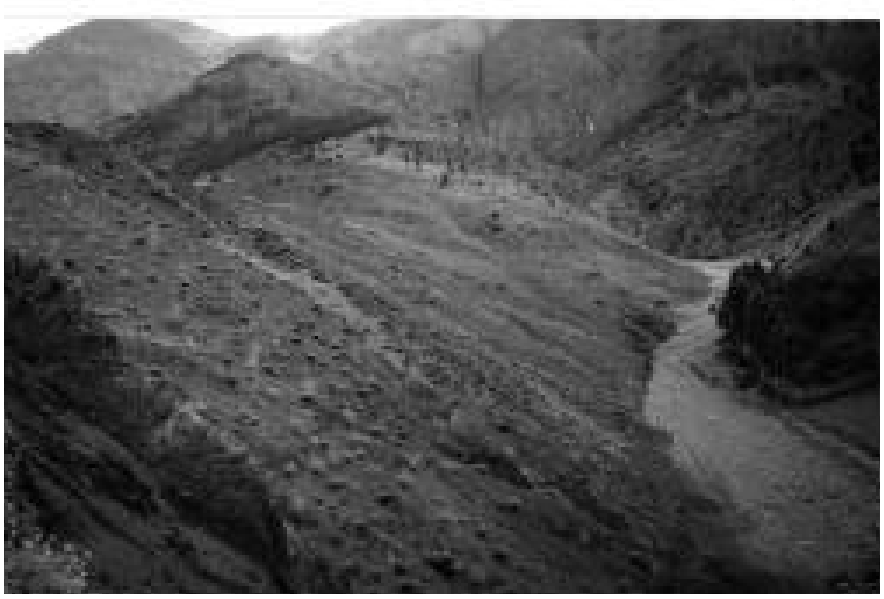

Fig. 2. A typical view of mountainous rangeland dominantly covered with A. microcephalus Willd.

Insufficient soil moisture, competition from non-forage plants and loss of the upper soil layer are important factors restricting re-vegetation with better plants in arid and semi-arid regions (Allen 1995). Shrubs are important plants for the rehabilitation of arid and semi-arid lands, because they grow successfully in degraded soils. Many species of shrubs are valuable for controlling erosion and providing animal forage in arid environments. Many species are salt tolerant.

Shrubs are adapted to adverse environments and many species are capable of providing green forage for livestock in early spring and in summer drought period. Seeds can be valuable feed 
sources for wild animals in winter. Shrubs are used as firewood and fruits are eaten and some are used medicinally. Their shade provide suitable seedbed habitat for herbaceous plants.

\section{Management Needs for Grazing Lands in Turkey}

Almost all of the rangelands in Turkey need moderate to drastic reclamation measures. The rangelands of Eastern Anatolia and in high elevation areas in the other regions may be improved by enhancing present plant cover by fertilization and regulation of grazing, but in the other areas rangeland vegetation needs to be totally re-established.

Water erosion is a critical problem especially on degraded rangelands (Figure 3). It is estimated that while 368 tons of soils from per $\mathrm{km}^{2}$ on average are lost to erosion every year in the world, 600 tons of soils from per $\mathrm{km}^{2}$ are lost to erosion in Turkey (Gunay 1995).

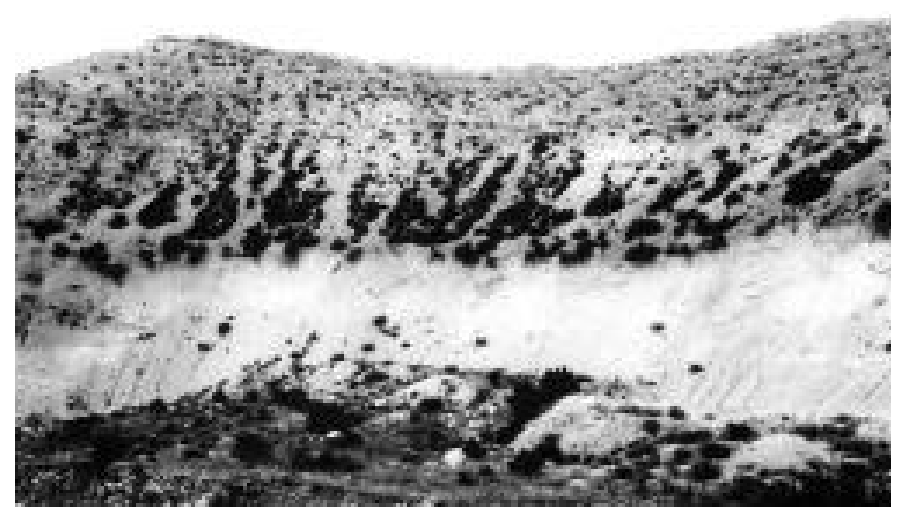

Fig. 3. An area in Eastern Anatolia Region with erosion problem sparsely covered by shrubs (i.e. Colutea sp., Cotinus sp., Juniperus sp., Quercus sp, Rhamnus sp. and Rosa sp. are common genus). The area in the mid dle rarely covered by shrubs is heavily degraded.

Important Turkish rangelands are located in high altitude areas. Snow is the most important water supply in these areas. Snow is moved from open areas by wind. Hilly sites on these rangelands lose their snow covers through wind storms and the other areas benefit from this snow movement. This affects uniformity of soil moisture over the area. If windbreaks were established with suitable shrub species into open range vegetation, a better distribution of soil water would be accomplished. Also forage production on the rangelands may be increased. A study on the windbreak effects of tall wheatgrass by Steppuhn and Waddington (1996) in Saskatchewan estimated that winter recharge of water in the upper $120 \mathrm{~cm}$ of soil was $22 \mathrm{~mm}$ greater in the windbreak area than in the open area. This extra water provided a $40 \%$ increase in hay yield of alfalfa.

On almost all of Turkey's rangelands, the herbaceous layer dries in the summer period with a considerable loss in forage value. Shrubs remain green in summer due to their rooting characteristics. If suitable shrub species can be established into open rangelands, green forage periods on these areas may be extended.

Another important problem on Turkish rangelands is salinity. About 80 million ha area in the Mediterranean Basin are affected by salinity (Osman 1996), 1.5 million ha of which are located in Turkey (Kantar and Elkoca 1998). Some shrub species such as Atriplex grown successfully in the area are affected by excess salinity. Research efforts should concentrate on salt tolerant shrub and other halophytic plant species to rehabilitate the areas affected by excess salt.

There is an immediate need to restore plant cover on these rangelands to protect soil resources. Mixtures of desirable shrub and herbaceous species are advantageous since grazing pressure will change to different species in different periods and soil moisture will be used more effectively with a variety of rooting characteristics.

\section{Recommendations for Change}

To stop further degradation of rangelands and increase productivity in these areas in Turkey the following short- and long-term measures should be taken;

1. Biological, morphological and ecological properties of native shrubs in Turkey should be determined.

2. Research should begin on shrubs which have value for forage production and erosion control.

3. A nationwide program should be started in collaborating with international institutes for the introduction and improvement of shrubs.

4. After suitable shrubs species are determined for every location, agronomic methods have to be determined for re-vegetation.

5. Southern districts of Turkey are affected by drought and salinity. Herbaceous shrubs like Atriplex sp. and Artemisia sp. should be given priority in these districts.

6. Turkey should develop and implement erosion control and re-vegetation programs.

7. In maquis vegetation of Mediterranean and Aegean Regions of Turkey, grazing should be regulated to reduce erosion.

8. It is important that Turkey immediately implement legislation to regulate the use of shrublands.

\section{References}

Allen, E.B., 1995. Restoration ecology: Limits and possibilities in arid and semiarid lands. Proc. Wildland Shrub and Arid Land Restoration Symp, Las Vegas, NV,. Intermountain Res. Sta. Gen. Tech. Rep. INT-GTR: 315, p. 7-15.

Genckan, M.S:, R. Avcioglu, H. Soya and O.O. Dogan, 1990. The Suggestions for the problems of usage, conservation and improvement of Turkey's rangelands (in Turkish). Proc. $3^{\text {rd }}$ Tech. Congr. of Turkish Agricultural Engineering, Ankara, p. 53-61.

Gunay, T., 1995. Forest, Deforestation, Soil and Erosion (in Turkish). TEMA Foundation Publ. No: 1, Istanbul, $85 \mathrm{p}$.

Kantar, F. and E. Elkoca, 1998. Salt tolerance in the crop plants (in Turkish). J. Faculty of Agric., Atatürk Univ., Erzurum, Turkey (in press).

Koc, A., 1995. The Effects of Topography and Soil Climate on Some Properties of Rangeland Vegetation (PhD Thesis in Turkish). Atatürk University, Faculty of Agriculture, Erzurum, Turkey.

Koç, A., A. Gokkus and Y. Serin, 1994. The state of Turkey's Rangelands and its importance for erosion problems (in Turkish). J. Ecol. and Environ., 13:36-41.

Osman, A., 1996. The battle for the steppe shrubs could help save the steppe. ICARDA Caravan, 3, Spring/Summer, 18-19.

Steppuhn, H. And J. Waddington, 1996. Conserving water and increasing alfalfa production using a tall wheatgrass windbreak system. J. Soil and Water Cons., 51, 439-445.

Yilmaz, O., 1993. Maquis Plants (in Turkish). Ankara University, Faculty of Agriculture Publications No: 1326, Ankara, 60 p.

Author is Faculty of Agriculture, Atatürk University, 25240 Erzurum, TURKEY. 